\title{
Herpes zoster and meningitis in an immunocompetent child: a case report
}

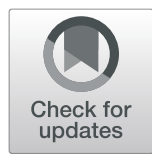

Ryu Yasuda ${ }^{1,2^{*}}$, Kisei Minami ${ }^{1}$, Akira Ogawa' ${ }^{1}$ Hideshi Okada², Runa Terakawa ${ }^{1}$, Yumi Koike ${ }^{1}$, Shinji Ogura², Kouichi Takeuchi ${ }^{1}$ and Tsukasa Higuchi ${ }^{1}$

\begin{abstract}
Background: Development of neurological complications of varicella zoster virus reactivation is relatively uncommon, particularly in an immunocompetent child.

Case presentation: An 11-year-old Asian girl presented with headache and skin rash on her left chest. She was diagnosed with meningitis, and herpes zoster was confirmed by polymerase chain reaction using cerebrospinal fluid. Acyclovir was administered intravenously. Given the favorable evolution of the clinical course, she was discharged from the hospital on day 8 of her illness. She had no apparent sequelae or comorbidities at the time of the 6-week follow-up.

Conclusions: Neurological complications such as meningitis due to varicella zoster virus reactivation are uncommon, especially in an immunocompetent child; no specific immune deficiency was identified in our patient. We conclude that, although rare, varicella zoster virus should be recognized as a potential cause of viral meningitis in immunocompetent children.
\end{abstract}

Keywords: Herpes zoster, Meningitis, Immunocompetent child, Acyclovir, Varicella zoster virus

\section{Background}

Varicella zoster virus (VZV) is a member of the herpesvirus family and causes varicella (chickenpox). After primary infection, VZV establishes latency in the cranial nerve and dorsal root ganglia. Cell-mediated immunity to VZV declines in elderly people or in the immunosuppressive state, and it leads to virus reactivation that can cause herpes zoster. Development of neurological complications due to VZV reactivation is considered to be relatively uncommon, particularly in an immunocompetent child. In this report, we describe herpes zoster and meningitis in an immunocompetent girl.

\section{Case presentation}

An 11-year-old Asian girl presented with headache and skin rash on the left side of her chest that had begun 3 days earlier. She had been diagnosed with varicella when she was 2 years old and therefore had no history of

\footnotetext{
* Correspondence: yasuryu@gifu-u.ac.jp

${ }^{1}$ Department of General Pediatrics, Nagano Children's Hospital, Nagano, Japan

${ }^{2}$ Department of Emergency and Disaster Medicine, Gifu University Graduate School of Medicine, 1-1 Yanagido, Gifu 501-1194, Japan
}

receiving the VZV vaccine. She did not have any episode associated with primary immunodeficiency.

Before the onset of illness, she had been feeling fatigue due to exhaustive preparation for a school gymnastics event over the course of several weeks. She visited the local clinic due to repeated afebrile vomiting and severe headache. On the same day, she was admitted to our hospital with a concern of meningitis.

Upon her admission, physical examination revealed a body temperature of $37.2{ }^{\circ} \mathrm{C}$, respiratory rate of 20 breaths/min, heart rate of 85 beats $/ \mathrm{min}$, and normal hemodynamic parameters with blood pressure of 117/68 $\mathrm{mmHg}$. She was noted to have a maculopapular rash evolving into vesicles with erythematous regions on the left side of her chest (Fig. 1). Her consciousness was clear, and her deep tendon reflexes were normal; Kernig's sign was negative, although she had neck stiffness.

A cerebrospinal fluid (CSF) examination revealed normal protein concentration $(36 \mathrm{mg} / \mathrm{dl})$, normal glucose level $(47 \mathrm{mg} / \mathrm{dl}$; blood glucose level, $92 \mathrm{mg} / \mathrm{dl})$, and lymphocytic pleocytosis (429 lymphocytes/ $\mu$ l). Bacterial culture of CSF yielded no growth. Varicella zoster virus (VZV) deoxyribonucleic acid (DNA) was detected in

(c) The Author(s). 2019 Open Access This article is distributed under the terms of the Creative Commons Attribution 4.0 International License (http://creativecommons.org/licenses/by/4.0/), which permits unrestricted use, distribution, and 

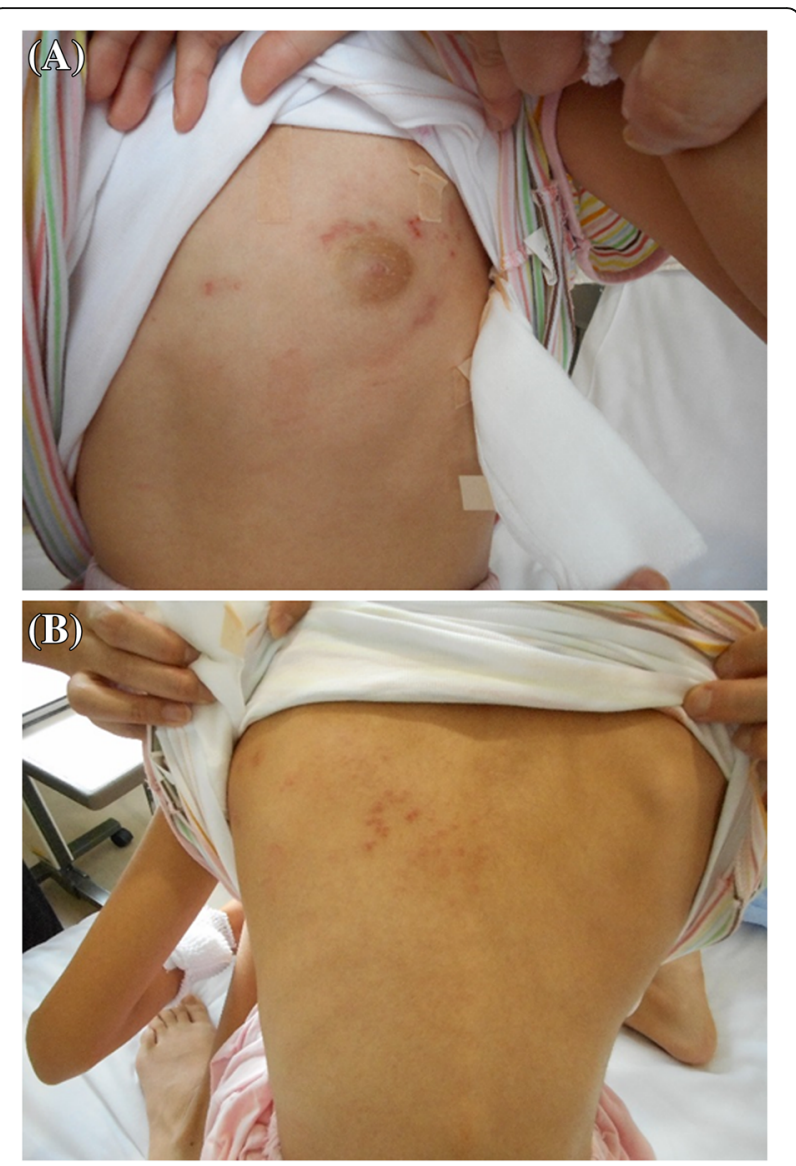

Fig. 1 Pictures of maculopapular rash evolving into vesicles with erythematous regions. a Ventral side. $\mathbf{b}$ Dorsal side

CSF by polymerase chain reaction (PCR) on day 5 . Results of blood examination were within normal ranges, including white blood cells $(7180 / \mu \mathrm{l})$, leukocytes (5220/ $\mu \mathrm{l})$, lymphocytes $(1507 / \mu \mathrm{l})$, monocytes $(287 / \mu \mathrm{l})$, eosinophils $(43 / \mu \mathrm{l})$, and basophils $(28 / \mu \mathrm{l})$. Results of VZV anticomplement immunofluorescence studies revealed values of $19 \mathrm{mg} / \mathrm{dl}$ for immunoglobulin G (IgG) and below $1 \mathrm{mg} / \mathrm{dl}$ for IgM, which indicates the previous infection and acquisition of humoral immunity against VZV. Moreover, there was no increase in the inflammatory biomarker levels. She had normal levels of quantitative immunoglobulins and lymphocyte markers: IgG 1106 $\mathrm{mg} / \mathrm{dl}$ (normal range, $870-1700 \mathrm{mg} / \mathrm{dl}$ ), IgA $71 \mathrm{mg} / \mathrm{dl}$ (normal range, $110-410 \mathrm{mg} / \mathrm{dl}$ ), IgM $132 \mathrm{mg} / \mathrm{dl}$ (normal range, 46-260 mg/dl), CD3 71.6\% (normal range, 59-88\%), CD4 $32.1 \%$ (normal range, 29-65\%), CD8 38.8\% (normal range, $13-40 \%$ ), CD4/CD8 ratio 0.83 (normal range, 0.9-3.2), CD19 12.8\% (normal range, 4-26\%), and CD56 15.5\% (normal range, 2-26\%).

She was diagnosed with aseptic meningitis and cutaneous manifestation of herpes zoster despite immunocompetence. Acyclovir (45 mg/kg/day) was administered intravenously for 3 days from admission. Because the symptoms of headache, neck stiffness, and skin rash eventually resolved, treatment was switched to oral valacyclovir $(75 \mathrm{mg} / \mathrm{kg} /$ day) for another 10 days. Given the favorable evolution of the illness, she was discharged from the hospital on day 8. She had no apparent sequelae or comorbidities at the time of the 6-week follow-up.

\section{Discussion and conclusions}

Herpes zoster is caused by the reactivation of VZV that remains in the sensory ganglion cells after primary infection of varicella or vaccination. Waning of cell-mediated immunity to VZV declines in the elderly or in the immunosuppressive state; this is thought to trigger the reactivation of herpes zoster because antibody remains unchanged or even increases with age $[1,2]$. Therefore, the incidence of herpes zoster infection is generally considered rare in immunocompetent people and in children.

The distribution of the age at onset of herpes zoster among immunocompetent and immunocompromised children was similar. Both had two peaks, namely at 4-5 years and 10-13 years of age [3]. Another report showed a different tendency with a single peak at 10-14 years of age [4].

Development of neurological complications such as meningitis in varicella zoster is believed to be rare. In a study of 859 adult patients with herpes zoster, meningitis was reported in only $0.5 \%$ cases [1]. Authors of another report reviewed 92 cases of children with herpes zoster and found 5 patients with meningitis (frequency, 5.4\%) [2]. Therefore, herpes zoster with aseptic meningitis in immunocompetent children seems to be rare. Similar cases have been published earlier, all of which were related to a history of varicella and reactivation of wild-type VZV [5-8] (Table 1).

For diagnosis, PCR analysis of viral particles in the CSF is crucial when aseptic meningitis is suspected. A rise in antibody titer between paired serum samples might also be helpful. Although dermatomal distribution of vesicular skin lesions is a typical symptom of varicella, an atypical case without any skin lesions has also been reported [6]. Thus, VZV should be raised as a pathogen of meningitis even without typical skin rash. Notably, recent reports have also described diagnosis of meningitis in the reactivation of vaccine strain VZV in immunocompetent children $[9,10]$ (Table 2). Both wild-type and vaccine strain VZV may be recognized as causes of meningitis in children. Generally, herpes simplex virus, enterovirus, cytomegalovirus, and Epstein-Barr virus should be listed as pathogens of meningitis in children; however, in our patient, we conducted a PCR examination for VZV only.

The optimal therapy for meningitis with varicella zoster infection has not been determined yet. However, the 
Table 1 Reported cases of herpes zoster and meningitis in immunocompetent children with wild-type varicella zoster virus

\begin{tabular}{|c|c|c|c|c|c|}
\hline Case No. & Age, sex & Onset of varicella & Clinical presentation & Treatment and outcome & Reference \\
\hline 1 & 3 years, $F$ & 2 months & Trigeminal skin rash and meningitis & & [5] \\
\hline 2 & 13 years, $F$ & 2 years & Trigeminal skin rash and meningitis & & [5] \\
\hline 3 & 15 years, $M$ & 5 years & Thoracic skin rash and meningitis & & [5] \\
\hline 4 & 12 years, $M$ & 19 months & Only severe headache & $\begin{array}{l}\text { Any antiviral drug was given, and } \\
\text { patient recovered }\end{array}$ & [6] \\
\hline 5 & 8 years, $\mathrm{M}$ & 6 months & $\begin{array}{l}\text { Painful skin rash in right thoracic } \\
\text { area and headache }\end{array}$ & $\begin{array}{l}\text { Treated with acyclovir for } 7 \text { days, and } \\
\text { patient recovered }\end{array}$ & [7] \\
\hline 6 & 14 years, $M$ & 3 years & $\begin{array}{l}\text { Maculopapular rash on left dorsal skin, } \\
\text { mild fever, and headache }\end{array}$ & $\begin{array}{l}\text { Treated with acyclovir } 30 \mathrm{mg} / \mathrm{kg} / \text { day for } \\
10 \text { days, and patient recovered }\end{array}$ & [8] \\
\hline 7 & 11 years, $F$ & 2 years & Skin rash and headache & $\begin{array}{l}\text { Treated with acyclovir } 45 \mathrm{mg} / \mathrm{kg} / \text { day for } \\
4 \text { days, oral valacyclovir } 75 \mathrm{mg} / \mathrm{kg} / \text { day for } \\
\text { another } 10 \text { days, and patient recovered }\end{array}$ & Our patient \\
\hline
\end{tabular}

$F$ female, $M$ male

guidelines issued by the Infectious Diseases Society of America recommend the administration of intravenous acyclovir at $10-15 \mathrm{mg} / \mathrm{kg}$ every $8 \mathrm{~h}$ for VZV encephalitis [11]. In our patient, the antiviral therapy was given for 14 days. The clinical prognosis of VZV meningitis seems to be appreciable, considering our patient's case and other case reports [5-10]. No neurological sequelae have been reported.

No specific immune deficiency was identified in our patient from either her medical history or blood examinations, such as immunoglobulins and several lymphocyte markers. Currently, we have no data to explain the co-occurrence of VZV reactivation and meningitis in the immunocompetent child. Several reports have suggested that VZV infection in the first year of life could be a risk factor for herpes zoster $[5,12]$. Low specific immune response, especially cellular response, due to the immature immune system in the first year of life is assumed to be the main reason for VZV reactivation in an immunocompetent child [12]. However, our patient had a history of chickenpox at the age of 2 years. Moreover, only two of seven patients reported had been diagnosed with chickenpox during the first year of life (Table 1). As another trigger of herpes zoster reactivation, our patient's feeling of fatigue due to exhaustive preparation for school gymnastic events over several weeks should be considered. Although we could not find a similar case report emphasizing fatigue as a key trigger of herpes zoster infection, there might be a relationship between these parameters in immunocompetent children. Interestingly, the state of puberty might be another trigger for herpes zoster infection. The level of estrogen, which is known as an inhibitor of cell-mediated immunity, rises rapidly at the beginning of puberty. Also, it is reported that the refusal response to allogenic skin graft is inhibited in mouse with pituitary excision [13]. However, we did not examine the role of pituitary hormones, such as estrogen, gonadotropin, and adrenocorticotropic hormone, which may reflect the state of puberty. Nevertheless, it is necessary to examine not only several lymphocyte markers but also the aforementioned hormones in order to clarify the factors affecting rare immune deficiencies in immunocompetent children.

In conclusion, neurological complications such as meningitis due to VZV reactivation are uncommon, especially in an immunocompetent child. No specific immune deficiency was identified in our patient. It may not be too difficult for an expert to list VZV as a cause of meningitis in immunocompetent children; however, it might be tough for a young trainee because aseptic meningitis with VZV is rare. We conclude that, although rare, VZV should be recognized as a potential cause of viral meningitis in immunocompetent children.

Table 2 Reported cases of herpes zoster and meningitis in immunocompetent children with varicella zoster virus vaccine strain

\begin{tabular}{|c|c|c|c|c|}
\hline Case No. & Age & Clinical presentation & Treatment and outcome & Reference \\
\hline 1 & 4 years old & Skin rash on right arm and meningitis & Treated with acyclovir and patient recovered & [9] \\
\hline 2 & 8 years old & Skin rash on left shoulder and meningitis & $\begin{array}{l}\text { Treated with acyclovir } 45 \mathrm{mg} / \mathrm{kg} / \text { day for } \\
7 \text { days and patient recovered }\end{array}$ & [9] \\
\hline 3 & 9 years old & Skin rash at left C5-C6 dermatome and meningitis & $\begin{array}{l}\text { Treated with acyclovir }\left(1500 \mathrm{mg} / \mathrm{m}^{2} / \text { day) for }\right. \\
8 \text { days and patient recovered }\end{array}$ & [9] \\
\hline 4 & 12 years old & Skin rash at left C5-C6 dermatome and meningitis & $\begin{array}{l}\text { Treated with acyclovir for } 7 \text { days and patient } \\
\text { recovered }\end{array}$ & [9] \\
\hline 5 & 7 years old & $\begin{array}{l}\text { Right arm rash and pain and fever, headache, } \\
\text { photophobia, and vomiting }\end{array}$ & $\begin{array}{l}\text { Treated with acyclovir for } 21 \text { days and patient } \\
\text { recovered }\end{array}$ & [10] \\
\hline
\end{tabular}




\section{Abbreviations}

CSF: Cerebrospinal fluid; IgG: Immunoglobulin G; IgM: Immunoglobulin M; PCR: Polymerase chain reaction; VZV: Varicella zoster virus

\section{Acknowledgements}

The authors thank the paramedical crews for the data.

\section{Funding}

None.

\section{Availability of data and materials}

The datasets obtained and analyzed in the current study are available from the corresponding author on reasonable request.

\section{Authors' contributions}

$R Y, K A, A O, R T, Y K, K T$, and $T H$ treated the patient. RY wrote the manuscript. $\mathrm{HO}$ and $\mathrm{SO}$ revised and edited the manuscript. All authors read and approved the final manuscript.

\section{Ethics approval and consent to participate}

In Japan, a case report does not require ethical approval. Our study adhered to the ethical guidelines for medical and health research involving human subjects established by the government of Japan.

\section{Consent for publication}

Written informed consent was obtained from the patient's legal guardians for publication of this case report and any accompanying images. A copy of the written consent is available for review by the Editor-in-Chief of this journal.

\section{Competing interests}

The authors declare that they have no competing interests.

\section{Publisher's Note}

Springer Nature remains neutral with regard to jurisdictional claims in published maps and institutional affiliations.

Received: 20 September 2018 Accepted: 12 April 2019

Published online: 15 June 2019

\section{References}

1. Galil K, Choo PW, Donahue JG, Platt R. The sequelae of herpes zoster. Arch Intern Med. 1997;157:1209-13.

2. Gershon AA, Gershon MD, Breuer J, Levin MJ, Oaklander AL, Griffiths PD. Advances understanding of the pathogenesis and epidemiology of herpes zoster. J Clin Virol. 2010;48 Suppl 1:S2-7.

3. Latif R, Shope TC. Herpes zoster in normal and immunocompromised children. Am J Dis Child. 1983:137:801-2.

4. Petursson G, Helgason S, Gudmundsson S, Sigurrdsson JA. Herpes zoster in children and adolescents. Pediatr Infect Dis J. 1982;61:905-8.

5. Takayama N, Yamada H, Kaku H, Minamitani M. Herpes zoster in immunocompetent and immunocompromised Japanese children. Pediatr Int. 2000;42:275-9.

6. Jhaveri R, Sankar R, Yadzani S, Cherry JD. Varicella-zoster virus: an overlooked case of aseptic meningitis. Pediatr Infect Dis J. 2003;22:96-7.

7. Szinnai G, Farron F, Bar G, Heininger U. Herpes zoster and aseptic meningitis in a previously healthy child. Eur J Pediatr. 2003;162:434-5.

8. Esposito S, Bosis S, Pinzani R, Morlacchi L, Senatore L, Principi N. A case of meningitis due to varicella zoster virus reactivation in an immunocompetent child. Ital J Pediatr. 2013;39:72.

9. Pahud BA, Glaser CA, Dekker CL, Arvin AM, Schmid DS. Varicella zoster disease of the central nervous system: epidemiological, clinical, and laboratory features 10 years after the introduction of the varicella vaccine. J Infect Dis. 2011;203:316-23.

10. Han JY, Hanson DC, Way SS. Herpes zoster and meningitis due to reactivation of varicella vaccine virus in an immunocompetent child. Pediatr Infect Dis J. 2011;30:266-8.

11. Tunkel AR, Glaser CA, Bloch C, Sejvar JJ, Marra CM, Roos L, Hartman BJ, Kaplan SL, Scheld WM, Whitley RJ. The management of encephalitis: clinical practice guidelines by the Infectious Diseases Society of America. Clin Infect Dis. 2008; $47: 303-27$.
12. Terada K, Kawano S, Yoshihiro K, Morita T. Varicella-zoster virus (VZV) reactivation is related to the low response of VZV-specific immunity after chickenpox in infancy. J Infect Dis. 1994;169:650-2.

13. Cosma J, Leonhardt H, Schwarz JA. Influence of the thymus-corticotropingrowth hormone interaction on the rejection of skin allografts in the rat. Ann N Y Acad Sci. 1975;249:387-401.

\section{Ready to submit your research? Choose BMC and benefit from:}

- fast, convenient online submission

- thorough peer review by experienced researchers in your field

- rapid publication on acceptance

- support for research data, including large and complex data types

- gold Open Access which fosters wider collaboration and increased citations

- maximum visibility for your research: over $100 \mathrm{M}$ website views per year

At $\mathrm{BMC}$, research is always in progress.

Learn more biomedcentral.com/submissions 